\title{
The Elastin-Derived Peptide VGVAPG Does Not Activate the Inflammatory Process in Mouse Cortical Astrocytes In Vitro
}

\author{
Konrad A. Szychowski ${ }^{1}$ (D) Jan Gmiński ${ }^{2}$ (D)
}

Received: 6 August 2019 /Revised: 12 September 2019 / Accepted: 13 September 2019 / Published online: 5 November 2019

(C) The Author(s) 2019

\begin{abstract}
During vascular aging or in pathological conditions in humans, elastin is degraded and its by-products, the elastin-derived peptides (EDPs), enter the blood circulation. EDPs may be detected in the serum of healthy subjects or people who suffered a stroke. Moreover, recent evidence suggests a potential role of inflammatory mechanisms in neurological conditions, which are usually not categorized as inflammatory. Therefore, the present in vitro study was conducted to investigate the impact of the VGVAPG peptide on the activation of inflammatory process in mouse primary astrocytes, which were maintained in phenol red-free DMEM/F12 supplemented with $10 \%$ fetal bovine serum. The cells were exposed to VGVAPG or VVGPGA peptides for 24 and $48 \mathrm{~h}$; this was

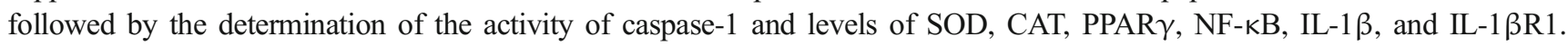
Furthermore, rosiglitazone — a PPAR $\gamma$ agonist—was applied. Our study pioneered the finding that the VGVAPG peptide increases caspase-1 activity in astrocytes in vitro. The VGVAPG peptide simultaneously decreases the release of IL-1 $\beta$ into the cell-culture medium from astrocytes. The ELISA method revealed that the VGVAPG peptide increases the protein expression of SOD1 whereas it decreases the expression of IL-1 $\beta R 1, C A T$, and NF- $\mathrm{KB}$. Therefore, the available data suggest that the VGVAPG peptide (concentration $10 \mathrm{nM}$ ) synergistically acts with agonists of PPAR $\gamma$ in mouse astrocytes. However, given the lack of sufficient data to explain the molecular mechanism of action of the VGVAPG peptide in the nervous system, more studies in this area are necessary.
\end{abstract}

Keywords Elastin-derived peptides $\cdot$ VGVAPG $\cdot$ Astrocyte $\cdot$ Inflammation

$\begin{array}{ll}\text { Abbreviations } \\ \text { CAT } & \text { Catalase } \\ \text { CNS } & \text { Central nervous system } \\ \text { DMSO } & \text { Dimethyl sulfoxide }\end{array}$

Highlights

- The VGVAPG peptide increases the activity of caspase-1 in astrocytes in vitro.

- The VGVAPG peptide decreases the release of IL-1 $\beta$ from astrocytes into the cell-culture medium.

- The VGVAPG peptide decreases the protein expression of IL-1 $\beta R 1$, CAT, and NF-kB.

- The VGVAPG peptide increases the protein expression of SOD1.

Konrad A. Szychowski

konrad.szychowski@gmail.com

1 Department of Clinical Biochemistry and Laboratory Diagnostics, Institute of Medicine, University of Opole, Oleska 48, 45-052 Opole, Poland

2 Department of Lifestyle Disorders and Regenerative Medicine, University of Information Technology and Management in Rzeszow, Sucharskiego 2, 35-225 Rzeszow, Poland

$\begin{array}{ll}\text { EDPs } & \text { Elastin-derived peptides } \\ \text { FBS } & \text { Fetal bovine serum } \\ \text { ICE } & \text { Interleukin-1-beta-converting enzyme } \\ \text { IL-1 } \beta & \text { Interleukin-1 beta } \\ \text { IL-1 } \beta \text { R1 } & \text { Interleukin 1 beta receptor 1 } \\ \text { MMPs } & \text { Matrix metalloproteinases } \\ \text { NF-kB } & \text { Nuclear factor kappa-light-chain-enhancer of ac- } \\ & \text { tivated B cells } \\ \text { PBS } & \text { Phosphate-buffered saline } \\ \text { PPAR } \gamma & \text { Peroxisome proliferator-activated receptor } \\ & \text { gamma } \\ \text { ROS } & \text { Reactive oxygen species } \\ \text { SOD1 } & \text { Superoxide dismutase 1 } \\ \text { T2DM } & \text { Type 2 diabetes mellitus } \\ \text { VGVAPG } & \text { Gly-Val-Ala-Pro-Gly }\end{array}$

\section{Introduction}

Elastin is mainly responsible for tissue elasticity and is an insoluble component of elastic fibers in the skin, lung, and 
arteries (Mecham 2012). Elastin can be degraded by several enzymes known as elastases. In humans, elastin is degraded during vascular aging or in pathological conditions, following which the by-products - elastin-derived peptides (EDPs) enter and persist in the blood circulation (Gayral et al. 2014). In research published so far, high elastase expression and activity have been noted in different immune cells such as macrophages, leukemic neutrophils, or microglia (Gudgeon et al. 2013; Liu et al. 2013). Moreover, in the aging brain, matrix metalloproteinases (MMPs) from microglia can degrade elastin, facilitate the migration of inflammatory cells in tissues, and thereby modulate their inflammatory activity (Liu et al. 2013). EDPs can be detected in the serum of healthy subjects, and their levels increase in patients after a stroke (Nicoloff et al. 2008; Tzvetanov et al. 2008). Moreover, elevated levels of EDPs are detected in type 2 diabetes mellitus (T2DM), systemic sclerosis, cancers, and pulmonary diseases (Nicoloff et al. 2010; Hong et al. 2012; Skjøt-Arkil et al. 2013; Nikolov et al. 2014). Furthermore, several papers have suggested that the presence of EDPs is a trigger mechanism, which can stimulate inflammatory processes in the human abdominal aorta, ligamentum flavum cells, and synovial cells (Satta et al. 1998; Chao et al. 2012; Kobayashi et al. 2017). In accordance with the principle of positive feedback, EDPs can further generate more EDPs, and the whole process is accelerating (Dale et al. 2016; Kobayashi et al. 2017). This positive feedback loop, also known as the Snowball phenomenon, leads to chronic inflammation that is associated with the abovementioned diseases (cancer, atherosclerosis, T2DM) (Coussens and Werb 2012; Calle and Fernandez 2012; Libby 2012). However, there is much evidence to suggest a potential role of inflammatory mechanisms even in neurological conditions, such as Alzheimer's disease, Parkinson's disease, Huntington's disease, amyotrophic lateral sclerosis, stroke, and traumatic brain injuries (Degan et al. 2018).

Different authors have opined that interleukin-1 beta (IL$1 \beta$ ) is a key pro-inflammatory cytokine in the central nervous system (CNS) (Moynagh 2005). IL-1 $\beta$ stimulates the production of adhesion molecules and chemokines in astrocytes (Moynagh et al. 1994; Bourke and Moynagh 1999). IL-1 $\beta$ is formed when its inactive precursor pro-IL-1 $\beta$ is activated by limited proteolysis through the interleukin-1-betaconverting enzyme (ICE), which is currently known as caspase-1 (Scheer 2013). At present, it is generally accepted that caspase-1 is not involved in apoptosis, but that its role is limited to the inflammatory process in immune cells (Miao et al. 2011; Strowig et al. 2012; Sollberger et al. 2014). However, caspase-1 can be activated in many nonimmune cell types, which include keratinocytes, astrocytes, hepatocytes, and cardiomyocytes, wherein IL- $1 \beta$ and -18 are not produced at significant levels and, therefore, suggests alternative functions for caspase-1 (Yazdi et al. 2010; Ganz et al. 2011). Several studies have shown caspase-1 to be a regulator of cellular responses to stress through the regulation of cytoprotective responses, tissue repair, and autophagy (Keller et al. 2008; Groß et al. 2012; Sun et al. 2013; Saitoh and Akira 2016). Nevertheless, caspase-1 was claimed to be a requirement for apoptosis in neuronal or endothelial cells by some authors (Friedlander 2003; Sollberger et al. 2014). This particular aspect of caspase-1 function may be especially important in hepatocytes, neurons, astrocytes, and cardiomyocytes, where cell and tissue stresses, aging, or damage can be the source of EDPs being released from the extracellular matrix (Ganz et al. 2011; Kaczmarek et al. 2013; Sun and Scott 2016).

The transcription nuclear factor kappa-light-chainenhancer of activated B cells (NF- $\mathrm{KB}$ ) is a crucial mediator in the IL-1 signaling pathway and acts as a major inductor in the production of adhesion molecules and cytokines (Moynagh 2005). Moreover, the presence of IL-1 $\beta$ stimulates the activation of the NF-KB pathway, which then initiates the production of increased amounts of IL-1 $\beta$ (Liu et al. 2017). However, rosiglitazone - a peroxisome proliferator-activated receptor $\gamma$ (PPAR $\gamma$ ) agonist (and other synthetic, e.g., thiazolidinediones, or endogenous, e.g., 15-DeoxyDelta12,14-prostaglandin J2 [15d-PGJ2], PPAR $\gamma$ agonists) - can interrupt the positive feedback loop of IL-1 $\beta$ through the increased production of the interleukin-1 receptor antagonist (IL-1Ra) in rat synovial fibroblasts (Moulin et al. 2005). Moreover, PPAR $\gamma$ agonists and glucocorticoids inhibit the DNA-binding activity of NF- $\mathrm{KB}$ and thereby disrupt the NF-KB pathway (Remels et al. 2009; Liu et al. 2017). However, recent data shows that PPAR $\gamma$ is essential for the proper activation of the inflammatory process and regulation of expression antioxidant enzymes such as superoxide dismutase 1 (SOD1) and catalase (CAT) (Kim and Yang 2013; Weber et al. 2018).

The present in vitro study was conducted to investigate the impact of the VGVAPG peptide and rosiglitazone on the activation of inflammatory process in mouse primary astrocytes.

\section{Materials and Methods}

\section{Reagents}

Dulbecco's Modified Eagle's Medium/Hams F-12 (DMEM/F12) without phenol red as well as trypsin, rosiglitazone, penicillin, streptomycin, amphotericin B, 3 - [(3 - cholamidopropyl)dime thyla mmonio ]- 1 propanesulfonate (CHAPS), 4-(2-hydroxyethyl)piperazine-1ethanesulfonic acid (HEPES), ethylenediaminetetraacetic acid (EDTA), DL-dithiothreitol (DTT), N- $\alpha$-acetyl-Tyr-Val-AlaAsp-p-nitroanilide (Ac-YVAD-pNA), and dimethyl sulfoxide (DMSO) were purchased from Sigma-Aldrich (St. Louis, MO, USA). The VGVAPG and VVGPGA peptides were 
synthesized by LipoPharm.pl (Gdańsk, Poland). Charcoal/ dextran-treated FBS was purchased from EURx (Gdańsk, Poland). ELISA kits for PPAR $\gamma$ (M0893), SOD1 (M2398), IL-1 $\beta$ (M0037), IL-1R1 (M0017), and CAT (M2605) were purchased from Elabscience Biotechnology (Wuhan, China). NF-kB (EM1230) was purchased from Wuhan Fine Co., Ltd. (Wuhan, China). Stock solutions of the VGVAPG and VVGPGA peptides were prepared in DMSO and, then, added to the DMEM/F12 medium. The final concentration of DMSO in the culture medium was always $0.1 \%$.

\section{Astrocyte-Enriched Cell Culture}

The experiments were conducted on mouse astrocyte cell cultures. All experimental procedures were approved by a Bioethics Commission (approval no. 46/2014; First Local Ethical Committee on Animal Testing at the Jagiellonian University in Krakow), as compliant with the laws of the European Union. The cell cultures were prepared from the fetuses of pregnant, female Swiss mice on Day 17/18 of gestation. After the isolation and digestion processes, the cells were centrifuged and the pellet was suspended in DMEM/ F12 1:1, without phenol red, that was supplemented with $10 \%$ FBS, $100 \mathrm{U} / \mathrm{mL}$ penicillin, $0.10 \mathrm{mg} / \mathrm{mL}$ streptomycin, and $250 \mathrm{ng} / \mathrm{mL}$ amphotericin B. Isolation was undertaken according to a previously described method that allows the separation of an almost pure culture of astrocytes ( $>98 \%$ astrocytes) (Szychowski et al., 2019b, supplementary data). The cultures of glial cells were maintained at $37{ }^{\circ} \mathrm{C}$ in a humidified atmosphere containing $5 \% \mathrm{CO}_{2}$. In the logarithmic phase after reaching $90 \%$ confluence, the cells were trypsinized with $0.25 \%$ trypsin $/ 0.05 \%$ EDTA and passaged onto an experimental plate. The astrocytes were respectively seeded at densities of $5 \times 10^{5}$ per well in a 96-well plate for colorimetric analysis and $60 \times 10^{5}$ per well in a six-well plate for protein analysis. The culture medium was changed prior to the experiment with the VGVAPG and VVGPGA peptides and tool compound selected for this study.

\section{Caspase-1 Activity}

Caspase-1 activity was assessed according to the method described by Nicholson et al. (1995), with some modifications. The cultured glial cells were lysed using lysis buffer $(50 \mathrm{mM}$ HEPES, pH 7.4, $100 \mathrm{mM} \mathrm{NaCl}, 0.1 \%$ CHAPS, 1 mM EDTA, $10 \%$ glycerol, and $10 \mathrm{mM} \mathrm{DTT}$ ) at $10{ }^{\circ} \mathrm{C}$ for $10 \mathrm{~min}$. After initial incubation, the lysates were incubated with the caspase1 substrate Ac-YVAD-pNA at $37{ }^{\circ} \mathrm{C}$. After 30 min, absorbance of the lysates at $405 \mathrm{~nm}$ was measured on a microplate reader (FilterMax F5 Multi-Mode microplate reader). The quantity of colorimetric product was continuously monitored for $120 \mathrm{~min}$.

\section{ELISA for SOD, CAT, PPARY, NF-KB, IL-1 $\beta$, and Interleukin 1 Beta Receptor 1 (IL-1 $\beta$ R1)}

The levels of SOD1 (M2398), CAT (M2605), PPAR $\gamma$ (M0893), NF-KB (EM1230), IL-1 $\beta$ (M0037), and IL1R1 (M0017) (purchased from Elabscience Biotechnology or Wuhan Fine Co., Ltd., Wuhan, China) proteins were determined through ELISA after 24 or $48 \mathrm{~h}$ of treatment with $10 \mathrm{nM}$ VGVAPG, $10 \mathrm{nM}$ VVGPGA or co-treatment with $10 \mu \mathrm{M}$ rosiglitazone. The expression of SOD, CAT, PPAR $\gamma$, NF- $k B$, and IL- $1 \beta R 1$ were determined in cell-culture lysate, whereas IL- $1 \beta$ release was measured in the cell-culture medium. These proteins were specifically detected with ELISA and subsequently subjected to quantitative sandwich enzyme immunoassay, which was conducted according to the manufacturer's instructions (Elabscience Biotechnology, Wuhan, China). Briefly, a 96-well plate was pre-coated with monoclonal antibodies specific to SOD, CAT, PPAR $\gamma, \mathrm{NF}-\mathrm{kB}, \mathrm{IL}-1 \beta$, and IL-1 $\beta R 1$. Standards and the collected cell extracts were added to the wells and incubated for $90 \mathrm{~min}$ at $37{ }^{\circ} \mathrm{C}$. Next, the liquid was removed, and $100 \mu \mathrm{L}$ biotinylated detection antibodies were added to the cultures for $60 \mathrm{~min}$. We washed the cells three times to remove any unbound substances and then added horseradish peroxidase-conjugated avidin. The cells were washed again, and $90 \mu \mathrm{L}$ substrate solution was added to the wells for $15 \mathrm{~min}$. Then, $50 \mu \mathrm{L}$ stop solution was added to terminate the reaction and absorbance was measured at $450 \mathrm{~nm}$; the value obtained was proportional to the amount of SOD, CAT, PPAR $\gamma$, NF-kB, IL- $1 \beta$, and IL$1 \beta R 1$, respectively. The total protein concentration was determined in triplicate in each sample by using a Thermo Fisher NanoDrop device.

\section{Statistical Analysis}

Data are presented as means \pm SD of three independent experiments. Each treatment was repeated six times $(n=6)$ and measured in triplicate. Experimental data were analyzed with one-way analysis of variance (ANOVA) followed by Tukey's multiple comparison test. Statistical significance was determined at $* * * p<0.001, * * p<0.01$, and $* p<0.05$ vs the control.

\section{Results}

\section{Caspase-1 Activity}

After 24-h exposure of mouse astrocytes to increasing concentrations (1-100 $\mathrm{nM}$ and 1-100 $\mu \mathrm{M})$ of the VGVAPG peptide, the activity of caspase- 1 increased at all of the studied 
concentrations (increase by $55.35-130.21 \%$ vs control). The VVGPGA peptide does not affect caspase-1 activity within cells (Fig. 1a). Similarly, after 48-h exposure of mouse astrocytes to increasing concentrations (1-100 $\mathrm{nM}$ and $1-100 \mu \mathrm{M})$ of the VGVAPG peptide, the activity of caspase-1 increased at all of the studied concentrations (increase by $36.83-26.31 \%$ vs control). The VVGPGA peptide does not affect caspase-1 activity in cells (Fig. 1b).

Following 24-h exposure of mouse astrocytes to $10 \mathrm{nM}$ VGVAPG peptide, the activity of caspase- 1 increased by $71.41 \%$, compared to the control. Treatment of astrocytes by $10 \mu \mathrm{M}$ rosiglitazone did not affect the activity of caspase-1. Moreover, in cells co-treated with $10 \mathrm{nM}$ VGVAPG and $10 \mu \mathrm{M}$ rosiglitazone, we did not observe changes in the activity of caspase-1 (Fig. 2a). After 48-h exposure of mouse astrocytes to $10 \mathrm{nM}$ VGVAPG peptide, the activity of caspase-1 increased by $27.45 \%$, compared to the control. Similarly, treatment of these astrocytes with $10 \mu \mathrm{M}$ rosiglitazone after 48-h exposure did not affect the activity of caspase- 1 . However, cell co-treatment with $10 \mathrm{nM}$ VGVAPG and $10 \mu \mathrm{M}$ rosiglitazone decreased the activity of caspase-1 by $31.38 \%$, compared to the control (Fig. 2b).
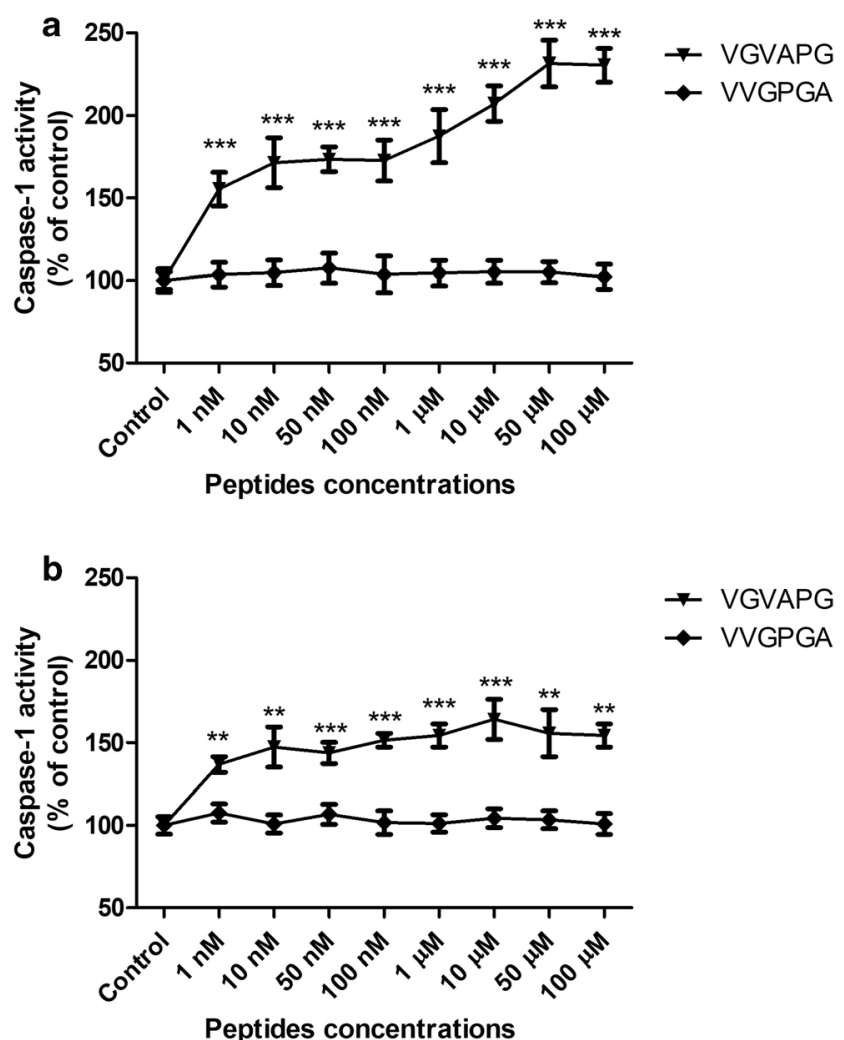

Fig. 1 Effect of the VGVAPG and VVGPGA peptides on the activity of caspase-1 after 24 (a) and 48 (b) h in mouse primary astrocytes in vitro. Data are expressed as means \pm SD of three independent experiments, each of which comprised six replicates per treatment group. ${ }^{*} p<0.01$ and $* * * p<0.001$, vs the control cells

\section{Protein Expression ELISA Assay}

\section{Expression of IL-1 $\beta$ and IL-1 $\beta R 1$}

After 24-h exposure of mouse astrocytes to $10 \mathrm{nM}$ VGVAPG peptide, we observed a decrease in the release of IL-1 $\beta$ into the cell-culture medium (decrease by $0.60 \mathrm{pg} / \mathrm{mL}$ vs control). Rosiglitazone does not affect the release of IL- $1 \beta$ into the cellculture medium. In cells co-treated with $10 \mathrm{nM}$ VGVAPG and $10 \mu \mathrm{M}$ rosiglitazone, the release of IL-1 $\beta$ into the culture medium decreased by $0.33 \mathrm{pg} / \mathrm{mL}$, compared to the group treated with $10 \mathrm{nM}$ VGVAPG (Fig. 3a). Following 48-h exposure of mouse astrocytes to $10 \mathrm{nM}$ VGVAPG peptide, the release of IL- $1 \beta$ into the cellculture medium decreased by $0.37 \mathrm{pg} / \mathrm{mL}$, compared to the control. In astrocytes treated with $10 \mu \mathrm{M}$ rosiglitazone,
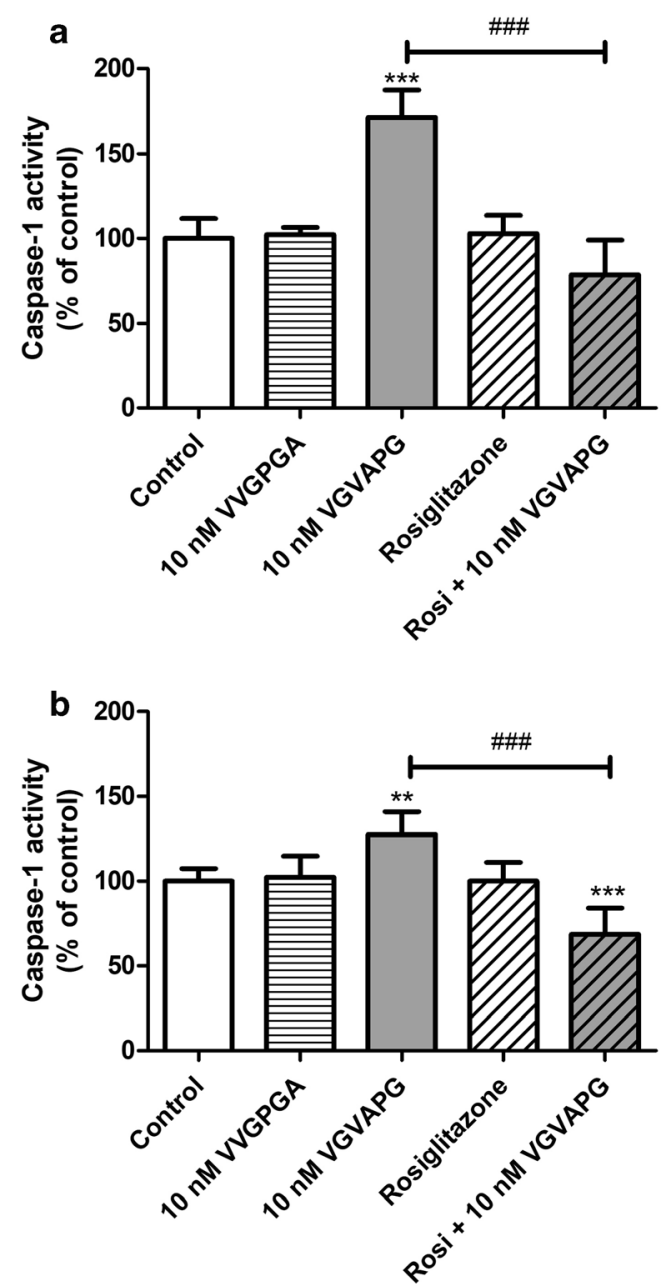

Fig. 2 Effect of the $10 \mathrm{nM}$ VGVAPG and VVGPGA peptides and $10 \mu \mathrm{M}$ rosiglitazone on the activity of caspase-1 after 24 (a) and 48 (b) h in mouse primary astrocytes in vitro. Data are expressed as means \pm SD of three independent experiments, each of which comprised six replicates per treatment group. $* * p<0.01$ and $* * * p<0.001$, vs the control cells. $\# \#$ 10.001 vs the group treated with the VGVAPG peptide 
we observed an increase in the release of IL- $1 \beta$ by $0.38 \mathrm{pg} /$ $\mathrm{mL}$, compared to the control. In cells co-treated with $10 \mathrm{nM}$ VGVAPG and $10 \mu \mathrm{M}$ rosiglitazone, the release of IL- $1 \beta$ increased by $1.03 \mathrm{pg} / \mathrm{mL}$ as compared to the group treated with $10 \mathrm{nM}$ VGVAPG (Fig. 3c).

Furthermore, following 24-h exposure of mouse astrocytes to $10 \mathrm{nM}$ VGVAPG peptide, we observed a decrease in the expression of IL-1 $\beta \mathrm{R} 1$ (decrease by $175.05 \mathrm{pg} / \mathrm{mL}$ vs control). Similarly, in astrocytes treated with $10 \mu \mathrm{M}$ rosiglitazone, we observed a decrease in the expression of IL-1ßR1 (by $40.23 \mathrm{pg} / \mathrm{mL}$ vs control). In cells co-treated with $10 \mathrm{nM}$ VGVAPG and $10 \mu \mathrm{M}$ rosiglitazone, the expression of IL$1 \beta R 1$ decreased by $30.66 \mathrm{pg} / \mathrm{mL}$ compared to the group treated with $10 \mathrm{nM}$ VGVAPG (Fig. 3b). Moreover, after 48-h exposure of mouse astrocytes to $10 \mathrm{nM}$ VGVAPG peptide, the expression of IL-1 $\beta \mathrm{R} 1$ decreased by $136.37 \mathrm{pg} /$ $\mathrm{mL}$, compared to the control. In astrocytes treated with $10 \mu \mathrm{M}$ rosiglitazone, we observed a decrease in IL$1 \beta R 1$ expression of $221.69 \mathrm{pg} / \mathrm{mL}$, compared to the control. After 48-h in cells co-treated with $10 \mathrm{nM}$ VGVAPG and $10 \mu \mathrm{M}$ rosiglitazone, the expression of IL-1 $\beta \mathrm{R} 1 \mathrm{did}$ not change when compared to the group treated with 10 nM VGVAPG (Fig. 3d).

\section{Expression of SOD and CAT}

After 24-h exposure of mouse astrocytes to $10 \mathrm{nM}$ VGVAPG peptide, the expression of SOD1 increased by $0.19 \mathrm{pg} / \mathrm{mL}$, compared to the control. Moreover, treatment of astrocytes with $10 \mu \mathrm{M}$ rosiglitazone increased the expression of SOD1 by $0.36 \mathrm{pg} / \mathrm{mL}$, compared to the control. In cells co-treated with $10 \mathrm{nM}$ VGVAPG and $10 \mu \mathrm{M}$ rosiglitazone, the expression of SOD1 increased by $0.21 \mathrm{pg} / \mathrm{mL}$ when compared to the group treated with $10 \mathrm{nM}$ VGVAPG (Fig. 4a). After 48-h exposure of mouse astrocytes to $10 \mathrm{nM}$ VGVAPG peptide, the expression of SOD1 increased by $0.20 \mathrm{pg} / \mathrm{mL}$, compared to the control. Treatment of astrocytes with $10 \mu \mathrm{M}$ rosiglitazone increased the expression of SOD1 by $0.17 \mathrm{pg} /$ $\mathrm{mL}$, compared to the control. In cells co-treated with $10 \mathrm{nM}$ VGVAPG and $10 \mu \mathrm{M}$ rosiglitazone, the expression of SOD1 increased by $0.08 \mathrm{pg} / \mathrm{mL}$ when compared to the group treated with $10 \mathrm{nM}$ VGVAPG (Fig. 4c).

After 24-h exposure of mouse astrocytes to $10 \mathrm{nM}$ VGVAPG peptide, the expression of CAT decreased by $7.14 \mathrm{ng} / \mathrm{mL}$, compared to the control. Treatment of astrocytes with $10 \mu \mathrm{M}$ rosiglitazone did not change the expression of CAT. In cells co-treated with $10 \mathrm{nM}$ VGVAPG and $10 \mu \mathrm{M}$
Fig. 3 Effect of the $10 \mathrm{nM}$ VGVAPG and VVGPGA peptides and $10 \mu \mathrm{M}$ rosiglitazone on the protein expression of IL$1 \beta$ and IL-1 $\beta$ R 1 after $24(\mathbf{a}, \mathbf{b})$ and $48(\mathbf{c}, \mathbf{d}) \mathrm{h}$ in mouse primary astrocytes in vitro. Data are expressed as means $\pm \mathrm{SD}$ of three independent experiments, each of which comprised six replicates per treatment group. ${ }^{* *} p<0.01$ and $* * * p<0.001$, vs the control cells. ${ }^{\# \#} p<0.01$ and ${ }^{\# \#} p<0.001$, vs the group treated with the VGVAPG peptide
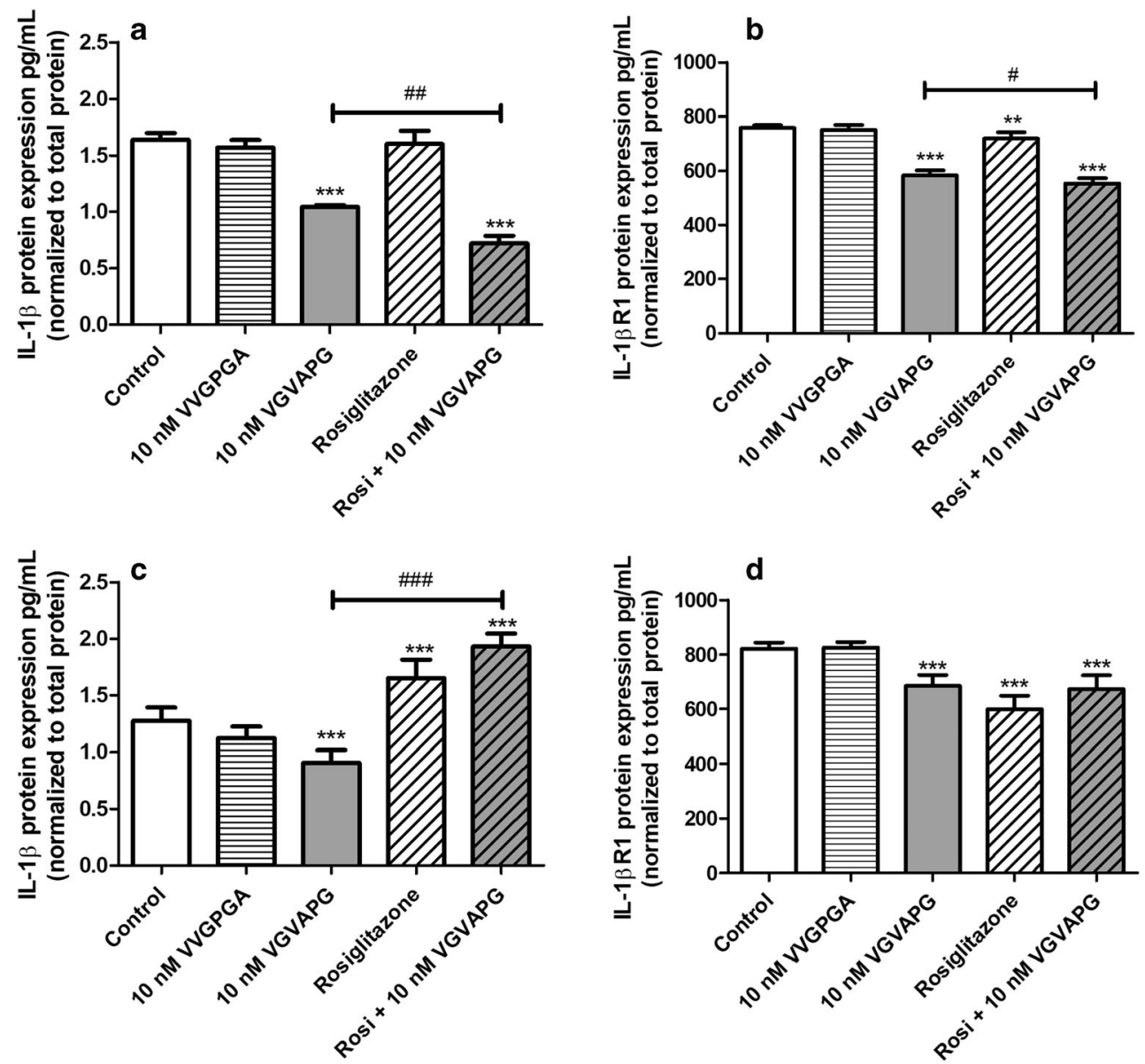
Fig. 4 Effect of the $10 \mathrm{nM}$ VGVAPG and VVGPGA peptides and $10 \mu \mathrm{M}$ rosiglitazone on protein expression of SOD1 and CAT after $24(\mathbf{a}, \mathbf{b})$ and 48 (c, d) $\mathrm{h}$ in mouse primary astrocytes in vitro. Data are expressed as means $\pm \mathrm{SD}$ of three independent experiments, each of which comprised six replicates per treatment group. ${ }^{* *} p<0.01$ and $* * * p<0.001$, vs the control cells. ${ }^{\#} p<0.05$ and ${ }^{\# \# \#} p<0.001$, vs the group treated with the VGVAPG peptide
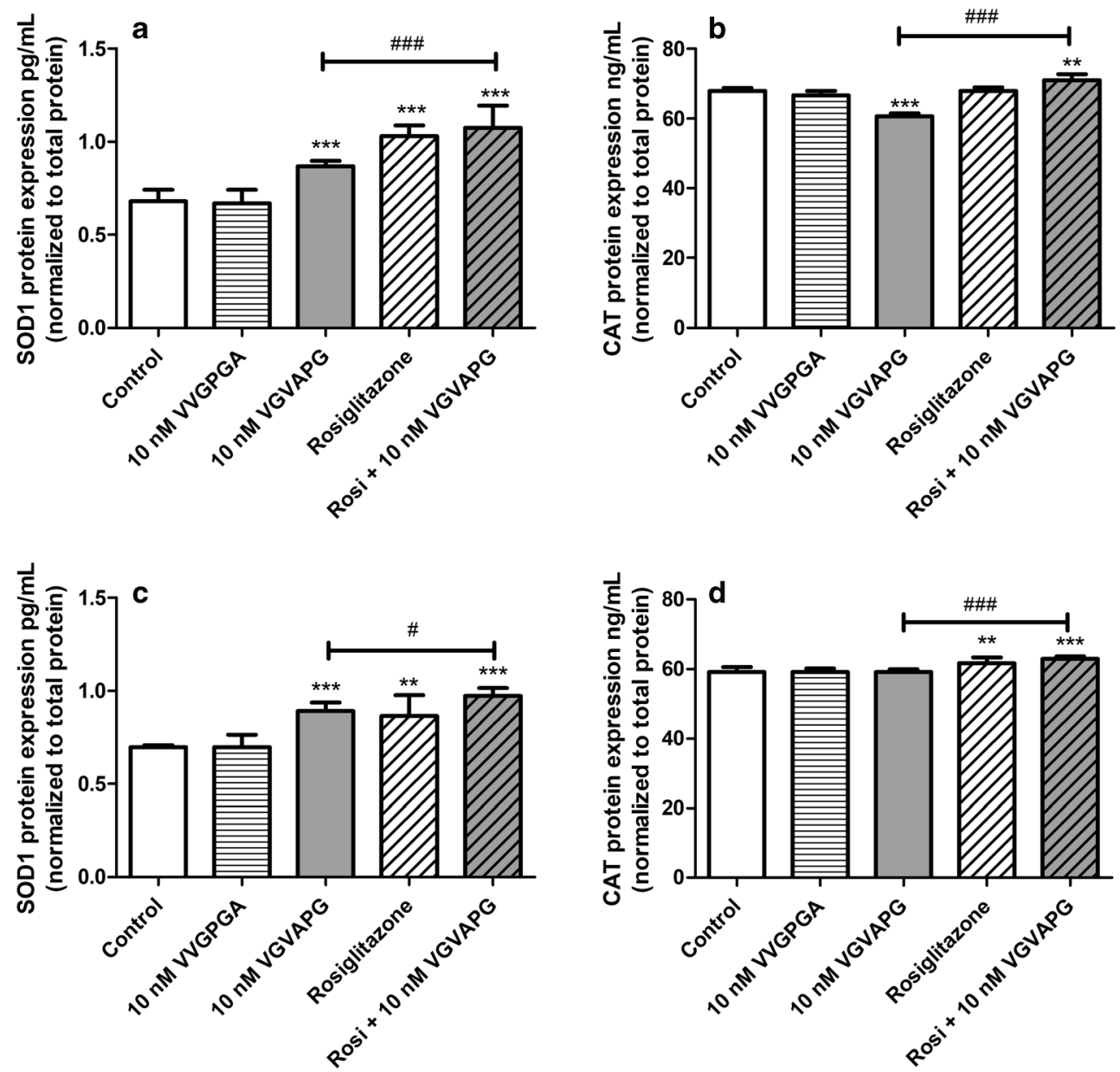

rosiglitazone, the expression of CAT increased by $10.27 \mathrm{ng} /$ $\mathrm{mL}$ as compared to that in the group treated with $10 \mathrm{nM}$ VGVAPG (Fig. 4b). After 48-h treatment of astrocytes with $10 \mu \mathrm{M}$ rosiglitazone, the expression of CAT increased by $2.55 \mathrm{ng} / \mathrm{mL}$, compared to the control. The exposure of astrocytes to $10 \mathrm{nM}$ VGVAPG did not change the expression of CAT. In the group co-treated with $10 \mathrm{nM} \mathrm{VGVAPG}$ and $10 \mu \mathrm{M}$ rosiglitazone, the expression of CAT increased by $3.78 \mathrm{ng} / \mathrm{mL}$ as compared to the group treated with $10 \mathrm{nM}$ VGVAPG (Fig. 4d).

\section{Expression of PPAR $\gamma$ and NF-кB}

Following 24-h exposure of mouse astrocytes to $10 \mathrm{nM}$ VGVAPG peptide, we did not observe any changes in the expression of NF- $\mathrm{KB}$. Treatment of astrocytes with $10 \mu \mathrm{M}$ rosiglitazone decreased the expression of NF-KB by $7.28 \mathrm{pg} /$ $\mathrm{mL}$, compared to the control. In cells co-treated with $10 \mathrm{nM}$ VGVAPG and $10 \mu \mathrm{M}$ rosiglitazone, the expression of $\mathrm{NF}-\kappa \mathrm{B}$ decreased by $13.89 \mathrm{pg} / \mathrm{mL}$ when compared to that in the group treated with $10 \mathrm{nM} \mathrm{VGVAPG} \mathrm{(Fig.} \mathrm{5a).} \mathrm{After}$ 48-h exposure of mouse astrocytes to $10 \mathrm{nM}$ VGVAPG peptide, the expression of $\mathrm{NF}-\mathrm{kB}$ decreased by $4.61 \mathrm{pg} /$
$\mathrm{mL}$, compared to the control. Furthermore, treatment of astrocytes by $10 \mu \mathrm{M}$ rosiglitazone decreased the expression of NF- $\mathrm{KB}$ by $13.50 \mathrm{pg} / \mathrm{mL}$, compared to the control. In cells co-treated with $10 \mathrm{nM}$ VGVAPG and $10 \mu \mathrm{M}$ rosiglitazone, the expression of $\mathrm{NF}-\kappa \mathrm{B}$ decreased by $11.63 \mathrm{pg} / \mathrm{mL}$ as compared to the group that was treated with $10 \mathrm{nM}$ VGVAPG (Fig. 5c).

After 24-h exposure of mouse astrocytes to $10 \mathrm{nM}$ VGVAPG peptide, the expression of PPAR $\gamma$ decreased by $2.03 \mathrm{ng} / \mathrm{mL}$, compared to the control. Treatment of astrocytes with $10 \mu \mathrm{M}$ rosiglitazone did not change the expression of PPAR $\gamma$. In cells co-treated with $10 \mathrm{nM} \mathrm{VGVAPG} \mathrm{and}$ $10 \mu \mathrm{M}$ rosiglitazone, the expression of PPAR $\gamma$ decreased by $1.78 \mathrm{ng} / \mathrm{mL}$ as compared to the group that was treated with 10 nM VGVAPG peptide (Fig. 5b). After 48-h exposure of mouse astrocytes to $10 \mathrm{nM}$ VGVAPG peptide, the expression of PPAR $\gamma$ did not change, compared to the control. Treatment of astrocytes by $10 \mu \mathrm{M}$ rosiglitazone increased the PPAR $\gamma$ expression by $2.04 \mathrm{ng} / \mathrm{mL}$, compared to the control. In cells co-treated with $10 \mathrm{nM}$ VGVAPG peptide and $10 \mu \mathrm{M}$ rosiglitazone, the expression of PPAR $\gamma$ increased by $2.12 \mathrm{ng} / \mathrm{mL}$ as compared to the group that was treated with 10 nM VGVAPG (Fig. 5d). 
Fig. 5 Effect of the $10 \mathrm{nM}$ VGVAPG and VVGPGA peptides and $10 \mu \mathrm{M}$ rosiglitazone on the protein expression of NF$\kappa \mathrm{B}$ and PPAR $\gamma$ after $24(\mathbf{a}, \mathbf{b})$ and $48(\mathbf{c}, \mathbf{d}) \mathrm{h}$ in mouse primary astrocytes in vitro. Data are expressed as means $\pm \mathrm{SD}$ of three independent experiments, each of which comprised six replicates per treatment group. $* p<0.05$ and $* * * p<0.001$, vs the control cells. ${ }^{\#} p<0.05$ and ${ }^{\# \# \#} p<0.001$, vs the group treated with the VGVAPG peptide
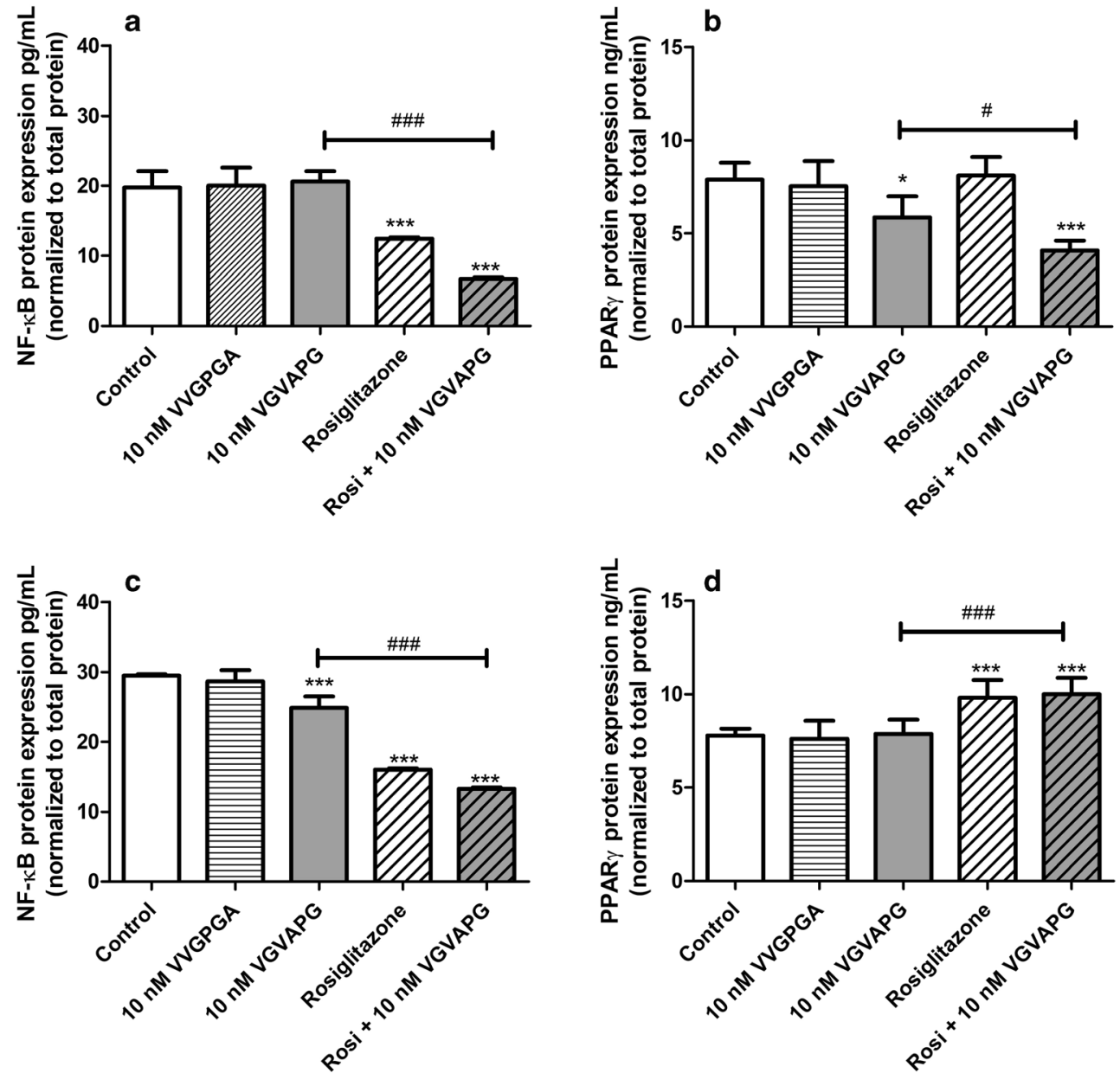

\section{Discussion}

Increased activity of caspase-1 is believed to lead to the initiation of the cell/tissue inflammatory process (Scheer 2013). Our experiments in this study generated the novel finding that the VGVAPG peptide at all of the studied concentrations $(1 \mathrm{nM}$ to $100 \mu \mathrm{M}$ ) increases the activity of caspase-1 in mouse primary astrocytes in vitro. In the experiments we conducted, the VVGPGA peptide that was used as a control did not activate caspase- 1 in the cells. To date, there are no data in the literature on the activity of caspase- 1 after the stimulation of astrocytes or other cell types with EDPs. However, different authors have consistently maintained that EDPs induced the production and/or secretion of IL- $1 \alpha$, IL- $1 \beta$, and IL- 6 in ligamentum flavum cells, synovial cells, and melanoma cell lines; therefore, we can assume that caspase- 1 should be activated by EDPs in these cells (Satta et al. 1998; Debret et al. 2006; Kobayashi et al. 2017). It is well documented that the mechanism of action of the VGVAPG peptide involves the hormesis phenomenon. The effect of the action of the VGVAPG peptide depends on the concentration that is used. The reaction curve takes the shape of a non-linear dose-response, usually with a "U", "N", or sinusoid shape (Senior et al. 1984; Fujimoto et al. 2000). Interestingly, in our experiments, we show that an increase in the activity of caspase- 1 is correlated with the concentration of the VGVAPG peptide that is used. The data from our experiments suggest a linear dependence between the activity of caspase- 1 and the concentration of the VGVAPG peptide after $24 \mathrm{~h}$ of exposition. Based on our previously published data, we chose the concentration of $10 \mathrm{nM}$ VGVAPG peptide for further experiments (Szychowski and Gmiński 2019a). Our experiments show that rosiglitazone (a PPAR $\gamma$ agonist) reduces the VGVAPG-peptide-stimulated activity of caspase-1. Moreover, the conducted experiments show that, after $24 \mathrm{~h}$, the VGVAPG peptide decreases both the secretion of IL- $1 \beta$ into the cell-culture medium and the expression of the IL-1 $\beta \mathrm{R} 1$ protein in cells. Cotreatment of the astrocytes with the VGVAPG peptide and rosiglitazone potentiated this effect. However, after 48-h astrocyte co-treatment with the VGVAPG peptide and rosiglitazone, we observed an increase in the release of IL$1 \beta$ into the cell-culture medium, whereas the expression of IL$1 \beta \mathrm{R} 1$ in cells continued to decrease. To date, researchers have described that rosiglitazone can interrupt the positive feedback loop of IL-1 $\beta$ through increased production of IL-1Ra in rat synovial fibroblasts (Moulin et al. 2005). 
Similarly, in the rat brain with cerebral ischemia, pioglitazone (a PPAR $\gamma$ agonist) reduced the level of IL- $1 \beta$ but upregulated IL-1Ra (Glatz et al. 2010). Moreover, different thiazolidinediones have been found to decrease the induction of pro-inflammatory genes of IL- 6 and IL-1 $\beta$ in rats with spinal cord injury (Park et al. 2006).

To date, it is well known that caspase- 1 can be activated by increased levels of ROS. Moreover, SOD1 is necessary for the production of mature IL-1 $\beta$ activity (Meissner et al. 2008; Harijith et al. 2014). Due to the crucial role of SOD1 in caspase-1 activation, we decided to measure the expression of SOD1 and CAT in mouse astrocytes. Our experiments show that, after 24- and 48-h exposure to the $10 \mathrm{nM}$ VGVAPG peptide, there was an increase in the expression of SOD1 in astrocytes; however, there was a decrease in the expression of CAT after 24-h exposure. Cell co-stimulation with the VGVAPG peptide and rosiglitazone increased the expression of SOD1 and CAT, compared to the expressions in the group treated with the VGVAPG peptide. Our previously published data show that the VGVAPG peptide increases the ROS production in mouse primary astrocytes and a human neuroblastoma (SH-SY5Y) cell line (Szychowski et al. 2019a; Szychowski and Gmiński 2019a). Furthermore, we observed that, after 24-h exposure of a SH-SY5Y cell line to $50 \mathrm{nM}$ VGVAPG peptide, there was decreased protein expression of SOD1 but the expression of CAT was unaltered (Szychowski et al. 2019a). On the other hand, after 48-h exposure of a SHSY5Y cell line to $50 \mathrm{nM}$ VGVAPG peptide, there was no change in the expression of SOD1 although there was decreased expression of CAT (Szychowski et al. 2019a). To date, rosiglitazone has been reported to increase the activities of SOD and CAT in the lung tissue of ovoalbumin-sensitized guinea pigs with bronchial asthma (El-Naa et al. 2015). Moreover, rosiglitazone exhibits neuroprotective properties by increasing the activities of CAT, $\mathrm{Cu} / \mathrm{Zn}-\mathrm{SOD}$, and $\mathrm{Mn}$ SOD in mice with traumatic brain injury (Yi et al. 2008).

On the other hand, several studies have shown that caspase1 has a regulatory function in cytoprotection, tissue repair, and autophagy in nonimmune cell types, such as keratinocytes, astrocytes, hepatocytes, and cardiomyocytes (Keller et al. 2008; Groß et al. 2012; Sun et al. 2013; Saitoh and Akira 2016). Stimulation of astrocytes by the VGVAPG peptide increases the activity of caspase- 1 with a simultaneous decrease in IL- $1 \beta$ secretion, we cannot rule out the function of this caspase in cytoprotection, tissue repair, or autophagy.

Due to the key role of PPAR $\gamma$ and NF-KB in the inflammatory process, the next step of our study was to investigate the expression of this protein in the studied cells. After 24-h exposure of mouse astrocytes to the VGVAPG peptide, the expression of PPAR $\gamma$ was slightly decreased, and this effect was potentiated by rosiglitazone. However, 48-h exposure to the VGVAPG peptide did not affect PPAR $\gamma$ expression compared to the control. In addition, our experiments show that 48-h exposure to the VGVAPG peptide decreased the expression of NF- $\mathrm{KB}$ in mouse astrocytes. Moreover, rosiglitazone potentiated the effect of the VGVAPG peptide. Our previously published data showed that PPAR $\gamma$ is involved in the mechanism of action of the VGVAPG peptide in mouse astrocytes and the SH-SY5Y cell line (Szychowski et al. 2019a; Szychowski and Gmiński 2019b). In more recently published research, an unexplained mechanism of action of the VGVAPG peptide causes activation of PPAR $\gamma$ and enhances its expression (Szychowski and Gmiński 2019b). The available data show that the VGVAPG peptide acts in similar/ synergistic ways to that of PPAR $\gamma$ agonists in mouse astrocytes and affects the pathways controlled by PPAR $\gamma$ (Szychowski et al. 2019a, b). Studies, to date, have reported that EDPs are involved via NF- $\mathrm{KB}$ in the inflammatory response in human melanoma cell lines and ligamentum flavum cells (Debret et al. 2006; Chao et al. 2012). Moreover, it is well known that PPAR $\gamma$ agonists and glucocorticoids inhibit the DNA-binding activity of NF- $\mathrm{KB}$ and thereby disrupt the NF-KB pathway (Remels et al. 2009; Liu et al. 2017). The PPAR $\gamma$-induced dysfunction of the NF- $k B$ pathway is the main mechanism of attenuation of the inflammatory process by PPAR $\gamma$ agonists (Kvandová et al. 2016; Scirpo et al. 2016). Therefore, according to our findings that the VGVAPG peptide has properties that stimulate PPAR $\gamma$ activation and expression, we postulate that this may be the mechanism by which inflammatory markers are decreased in mouse astrocytes.

\section{Conclusion}

Our report presents the novel finding that the VGVAPG peptide increases the activity of caspase-1 in astrocytes in vitro. Simultaneously, the VGVAPG peptide decreases IL-1 $\beta$ release into the cell-culture medium from astrocytes. An analysis of protein expression using the ELISA method revealed that the VGVAPG peptide increases the protein expression of SOD1 whereas it decreases the expression of IL-1 $\beta$ R1, CAT, and NF- $\mathrm{KB}$. Therefore, the available data suggests that, at a concentration of $10 \mathrm{nM}$, the VGVAPG peptide acts synergistically with agonists of PPAR $\gamma$ in mouse astrocytes. However, due to the lack of sufficient data to explain the molecular mechanism of action of the VGVAPG peptide in the nervous system, more studies on this topic are necessary.

Acknowledgments This work was financially supported by statutory funds from the University of Information Technology and Management in Rzeszow, Poland (grant no. DS MN 503-05-02-03).

Author Contribution Statement KS conceived and designed the research. KS conducted experiments. KS analyzed data. KS and JG wrote the manuscript. All authors read and approved the manuscript. 


\section{Compliance with Ethical Standards}

All procedures were performed in accordance with the National Institutes of Health Guidelines for the Care and Use of Laboratory Animals and were approved by a Bioethics Commission (no. 46/2014) as compliant with Polish law.

Conflict of Interests The authors declare that they have no conflict of interests.

Open Access This article is distributed under the terms of the Creative Commons Attribution 4.0 International License (http:// creativecommons.org/licenses/by/4.0/), which permits unrestricted use, distribution, and reproduction in any medium, provided you give appropriate credit to the original author(s) and the source, provide a link to the Creative Commons license, and indicate if changes were made.

\section{References}

Bourke E, Moynagh PN (1999) Antiinflammatory effects of glucocorticoids in brain cells, independent of NF-kappa B. J Immunol 163: 2113-2119

Calle MC, Fernandez ML (2012) Inflammation and type 2 diabetes. Diabetes Metab 38:183-191. https://doi.org/10.1016/j.diabet.2011. 11.006

Chao YH, Yang HS, Sun MG, Sun JS, Chen MH (2012) Elastin-derived peptides induce inflammatory responses through the activation of NF-KB in human ligamentum flavum cells. Connect Tissue Res 53: 407-414. https://doi.org/10.3109/03008207.2012.679368

Coussens LM, Werb Z (2012) Inflammation and cancer. Nature 420:860 867. https://doi.org/10.1038/nature01322

Dale MA, Xiong W, Carson JS, Suh MK, Karpisek AD, Meisinger TM, Casale GP, Baxter BT (2016) Elastin-derived peptides promote abdominal aortic aneurysm formation by modulating M1/M2 macrophage polarization. J Immunol 196:4536-4543. https://doi.org/10. 4049/jimmunol.1502454

Debret R, Le Naour RR, Sallenave JM et al (2006) Elastin fragments induce IL-1 $\beta$ upregulation via NF- $\mathrm{KB}$ pathway in melanoma cells. J Invest Dermatol 126:1860-1868. https://doi.org/10.1038/sj.jid. 5700337

Degan D, Ornello R, Tiseo C, Carolei A, Sacco S, Pistoia F (2018) The role of inflammation in neurological disorders. Curr Pharm Des 24:1485-1501. https://doi.org/10.2174/ 1381612824666180327170632

El-Naa MM, El-Refaei MF, Nasif WA et al (2015) In-vivo antioxidant and anti-inflammatory activity of rosiglitazone, a peroxisome proliferator-activated receptor-gamma (PPAR- $\gamma$ ) agonists in animal model of bronchial asthma. J Pharm Pharmacol 67:1421-1430. https://doi.org/10.1111/jphp.12445

Friedlander RM (2003) Apoptosis and caspases in neurodegenerative diseases. N Engl J Med 348:1365-1375. https://doi.org/10.1056/ NEJMra022366

Fujimoto N, Tajima S, Ishibashi A (2000) Elastin peptides induce migration and terminal differentiation of cultured keratinocytes via $67 \mathrm{kDa}$ elastin receptor in vitro: $67 \mathrm{kDa}$ elastin receptor is expressed in the keratinocytes eliminating elastic materials in elastosis perforans serpiginosa. J Invest Dermatol 115:633-639. https://doi.org/10. 1046/j.1523-1747.2000.00117.x

Ganz M, Csak T, Szabo G et al (2011) Fatty acid and endotoxin activate inflammasomes in mouse hepatocytes that release danger signals to stimulate immune cells. Hepatology 54:133-144. https://doi.org/10. 1002/hep.24341
Gayral S, Garnotel R, Castaing-Berthou A, Blaise S, Fougerat A, Berge E, Montheil A, Malet N, Wymann MP, Maurice P, Debelle L, Martiny L, Martinez LO, Pshezhetsky AV, Duca L, Laffargue M (2014) Elastin-derived peptides potentiate atherosclerosis through the immune Neu1-PI3K $\gamma$ pathway. Cardiovasc Res 102:118-127. https://doi.org/10.1093/cvr/cvt336

Glatz T, Stöck I, Nguyen-Ngoc M, Gohlke P, Herdegen T, Culman J, Zhao Y (2010) Peroxisome-proliferator-activated receptors $\gamma$ and peroxisome-proliferator-activated receptors $\beta / \delta$ and the regulation of interleukin 1 receptor antagonist expression by pioglitazone in ischaemic brain. J Hypertens 28:1488-1497. https://doi.org/10. 1097/HJH.0b013e3283396e4e

Groß O, Yazdi AS, Thomas CJ, Masin M, Heinz LX, Guarda G, Quadroni M, Drexler SK, Tschopp J (2012) Inflammasome activators induce interleukin- $1 \alpha$ secretion via distinct pathways with differential requirement for the protease function of caspase-1. Immunity 36:388-400. https://doi.org/10.1016/j.immuni.2012.01. 018

Gudgeon CJ, Harrington KH, Laszlo GS, Alonzo TA, Gerbing RB, Gamis AS, Raimondi SC, Hirsch BA, Meshinchi S, Walter RB (2013) High expression of neutrophil elastase predicts improved survival in pediatric acute myeloid leukemia: a report from the Children's Oncology Group. Leuk Lymphoma 54:202-204. https://doi.org/10.3109/10428194.2012.700480

Harijith A, Ebenezer DL, Natarajan V (2014) Reactive oxygen species at the crossroads of inflammasome and inflammation. Front Physiol 5: 1-11. https://doi.org/10.3389/fphys.2014.00352

Hong YJ, Kim J, Oh BR, Lee YJ, Lee EY, Lee EB, Lee SH, Song YW (2012) Serum elastin-derived peptides and anti-elastin antibody in patients with systemic sclerosis. J Korean Med Sci 27:484-488. https://doi.org/10.3346/jkms.2012.27.5.484

Kaczmarek A, Vandenabeele P, Krysko DV (2013) Necroptosis: the release of damage-associated molecular patterns and its physiological relevance. Immunity 38:209-223. https://doi.org/10.1016/j.immuni. 2013.02.003

Keller M, Rüegg A, Werner S, Beer HD (2008) Active caspase-1 is a regulator of unconventional protein secretion. Cell 132:818-831. https://doi.org/10.1016/j.cell.2007.12.040

Kim T, Yang Q (2013) Peroxisome-proliferator-activated receptors regulate redox signaling in the cardiovascular system. World J Cardiol 5: 164-174. https://doi.org/10.4330/wjc.v5.i6.164

Kobayashi K, Jokaji R, Miyazawa-Hira M, Takatsuka S, Tanaka A, Ooi K, Nakamura H, Kawashiri S (2017) Elastin-derived peptides are involved in the processes of human temporomandibular disorder by inducing inflammatory responses in synovial cells. Mol Med Rep 16:3147-3154. https://doi.org/10.3892/ mmr.2017.7012

Kvandová M, Majzúnová M, Dovinová I (2016) The role of PPAR $\gamma$ in cardiovascular diseases. Physiol Res 65:343-363

Libby P (2012) Inflammation in atherosclerosis. Arterioscler Thromb Vasc Biol 32:2045-2051. https://doi.org/10.1161/ATVBAHA.108. 179705

Liu Y, Zhang M, Hao W, Mihaljevic I, Liu X, Xie K, Walter S, Fassbender K (2013) Matrix metalloproteinase-12 contributes to neuroinflammation in the aged brain. Neurobiol Aging 34:12311239. https://doi.org/10.1016/j.neurobiolaging.2012.10.015

Liu T, Zhang L, Joo D, Sun S-C (2017) NF-kB signaling in inflammation. Signal Transduct Target Ther 2:17023. https://doi.org/10.1038/ sigtrans.2017.23

Mecham RP (2012) Overview of extracellular matrix. Curr Protoc cell Biol Chapter 10:Unit 10.1. https://doi.org/10.1002/0471143030. cb1001s57

Meissner F, Molawi K, Zychlinsky A (2008) Superoxide dismutase 1 regulates caspase-1 and endotoxic shock. Nat Immunol 9:866872. https://doi.org/10.1038/ni.1633 
Miao EA, Rajan JV, Aderem A (2011) Caspase-1-induced pyroptotic cell death. Immunol Rev 243:206-214. https://doi.org/10.1111/j.1600065X.2011.01044.X

Moulin D, Bianchi A, Boyault S, Sebillaud S, Koufany M, Francois M, Netter P, Jouzeau JY, Terlain B (2005) Rosiglitazone induces interleukin-1 receptor antagonist in interleukin-1beta-stimulated rat synovial fibroblasts via a peroxisome proliferator-activated receptor beta/delta-dependent mechanism. Arthritis Rheum 52:759-769. https://doi.org/10.1002/art.20868

Moynagh PN (2005) The interleukin-1 signalling pathway in astrocytes: a key contributor to inflammation in the brain. J Anat 207:265-269. https://doi.org/10.1111/j.1469-7580.2005.00445.x

Moynagh PN, Williams DC, O'Neill LA (1994) Activation of NF-kappa $\mathrm{B}$ and induction of vascular cell adhesion molecule-1 and intracellular adhesion molecule-1 expression in human glial cells by IL-1. Modulation by antioxidants. J Immunol 153:2681-2690

Nicholson DW, Ali A, Thornberry NA, Vaillancourt JP, Ding CK, Gallant M, Gareau Y, Griffin PR, Labelle M, Lazebnik YA, Munday NA, Raju SM, Smulson ME, Yamin TT, Yu VL, Miller DK (1995) Identification and inhibition of the ICE/CED-3 protease necessary for mammalian apoptosis. Nature 376:37-43. https://doi.org/10. $1038 / 376037 \mathrm{a} 0$

Nicoloff G, Tzvetanov P, Christova P, Baydanoff S (2008) Detection of elastin derived peptides in cerebrospinal fluid of patients with first ever ischaemic stroke. Neuropeptides 42:277-282. https://doi.org/ 10.1016/j.npep.2008.02.003

Nicoloff G, Deliiyski T, Nikolov A (2010) Detection of serum collagen type iv and elastin derived peptides in patients with breast cancer. Diabetol Croat 39:83-93

Nikolov A, Tsinlikov I, Nicoloff G, Tsinlikova I, Blazhev A, Garev A (2014) Abnormal levels of age-elastin derived peptides in sera of diabetic patients with arterial hypertension. Cent Eur J Immunol 39: 345-351. https://doi.org/10.5114/ceji.2014.45946

Park S-W, Yi J-H, Miranpuri G, Satriotomo I, Bowen K, Resnick DK, Vemuganti R (2006) Thiazolidinedione class of peroxisome proliferator-activated receptor agonists prevents neuronal damage, motor dysfunction, myelin loss, neuropathic pain, and inflammation after spinal cord injury in adult rats. J Pharmacol Exp Ther 320: 1002-1012. https://doi.org/10.1124/jpet.106.113472

Remels AHV, Langen RCJ, Gosker HR, Russell AP, Spaapen F, Voncken JW, Schrauwen P, Schols AMWJ (2009) PPAR $\gamma$ inhibits NF-kBdependent transcriptional activation in skeletal muscle. Am J Physiol Metab 297:E174-E183. https://doi.org/10.1152/ajpendo. 90632.2008

Saitoh T, Akira S (2016) Regulation of inflammasomes by autophagy. J Allergy Clin Immunol 138:28-36. https://doi.org/10.1016/j.jaci. 2016.05.009

Satta J, Laurila A, Päk̈kkö P, Haukipuro K, Sormunen R, Parkkila S, Juvonen T (1998) Chronic inflammation and elastin degradation in abdominal aortic aneurysm disease: an immunohistochemical and electron microscopic study. Eur J Vasc Endovasc Surg 15:313-319. https://doi.org/10.1016/s1078-5884(98)80034-8

Scheer JM (2013) Caspase-1. In: Handbook of proteolytic enzymes. Elsevier, pp 2237-2243

Scirpo R, Fiorotto R, Villani A et al (2016) Stimulation of nuclear receptor PPAR- $\gamma$ limits NF-kB-dependent inflammation in mouse cystic fibrosis biliary epithelium. Hepatology 62:1551-1562. https://doi. org/10.1002/hep.28000.Stimulation

Senior RM, Griffin GL, Mecham RP et al (1984) Val-Gly-Val-Ala-ProGly, a repeating peptide in elastin, is chemotactic for fibroblasts and monocytes. J Cell Biol 99:870-874. https://doi.org/10.1083/jcb.99. 3.870
Skjøt-Arkil H, Clausen RE, Rasmussen LM, Wang W, Wang Y, Zheng Q, Mickley H, Saaby L, Diederichsen ACP, Lambrechtsen J, Martinez FJ, Hogaboam CM, Han ML, Larsen MR, Nawrocki A, Vainer B, Krustrup D, Bjørling-Poulsen M, Karsdal MA, Leeming DJ (2013) Acute myocardial infarction and pulmonary diseases result in two different degradation profiles of elastin as quantified by two novel ELISAs. PLoS One 8:e60936. https://doi.org/10.1371/journal.pone. 0060936

Sollberger G, Strittmatter GE, Garstkiewicz M, Sand J, Beer HD (2014) Caspase-1: the inflammasome and beyond. Innate Immun 20:115125. https://doi.org/10.1177/1753425913484374

Strowig T, Henao-Mejia J, Elinav E, Flavell R (2012) Inflammasomes in health and disease. Nature 481:278-286. https://doi.org/10.1038/ nature 10759

Sun Q, Scott MJ (2016) Caspase-1 as a multifunctional inflammatory mediator: noncytokine maturation roles. J Leukoc Biol 100:961967. https://doi.org/10.1189/jlb.3mr0516-224r

Sun Q, Gao W, Loughran P, Shapiro R, Fan J, Billiar TR, Scott MJ (2013) Caspase 1 activation is protective against hepatocyte cell death by up-regulating beclin 1 protein and mitochondrial autophagy in the setting of redox stress. J Biol Chem 288:15947-15958. https://doi. org/10.1074/jbc.M112.426791

Szychowski KA, Gmiński J (2019a) The VGVAPG peptide regulates the production of nitric oxide synthases and reactive oxygen species in mouse astrocyte cells in vitro. Neurochem Res 44:1127-1137. https://doi.org/10.1007/s11064-019-02746-z

Szychowski KA, Gmiński J (2019b) Impact of elastin-derived VGVAPG peptide on bidirectional interaction between peroxisome proliferator-activated receptor gamma (Ppar $\gamma)$ and betagalactosidase $(\beta-\mathrm{Gal})$ expression in mouse cortical astrocytes in vitro. Naunyn Schmiedeberg's Arch Pharmacol 392:405-413. https://doi.org/10.1007/s00210-018-1591-4

Szychowski KA, Rombel-Bryzek A, Dołhańczuk-Śródka A, Gmiński J (2019a) Antiproliferative effect of elastin-derived peptide VGVAPG on SH-SY5Y neuroblastoma cells. Neurotox Res 36:503-514. https://doi.org/10.1007/s12640-019-00040-y

Szychowski KA, Wójtowicz AK, Gmiński J (2019b) Impact of elastinderived peptide VGVAPG on matrix Metalloprotease- 2 and -9 and the tissue inhibitor of Metalloproteinase-1, $-2,-3$ and -4 mRNA expression in mouse cortical glial cells in vitro. Neurotox Res 35: 100-110. https://doi.org/10.1007/s12640-018-9935-x

Tzvetanov P, Nicoloff G, Rousseff R, Christova P (2008) Increased levels of elastin-derived peptides in cerebrospinal fluid of patients with lacunar stroke. Clin Neurol Neurosurg 110:239-244. https://doi. org/10.1016/j.clineuro.2007.11.003

Weber KJ, Sauer M, He L, Tycksen E, Kalugotla G, Razani B, Schilling JD (2018) PPAR $\gamma$ deficiency suppresses the release of IL-1 $\beta$ and IL- $1 \alpha$ in macrophages via a type 1 IFN-dependent mechanism. J Immunol 201:ji1800224. https://doi.org/10.4049/jimmunol. 1800224

Yazdi AS, Drexler SK, Tschopp J (2010) The role of the Inflammasome in nonmyeloid cells. J Clin Immunol 30:623-627. https://doi.org/10. 1007/s10875-010-9437-y

Yi JH, Park SW, Brooks N, Lang BT, Vemuganti R (2008) PPAR $\gamma$ agonist rosiglitazone is neuroprotective after traumatic brain injury via anti-inflammatory and anti-oxidative mechanisms. Brain Res 1244: 164-172. https://doi.org/10.1016/j.brainres.2008.09.074

Publisher's Note Springer Nature remains neutral with regard to jurisdictional claims in published maps and institutional affiliations. 